2018-10-19

\title{
Raman spectroscopy detects biochemical changes due to different cell culture environments in live cells in vitro
}

\author{
Mahmoud Gargotti \\ Technological University Dublin, mahmoud.gargotti@mydit.ie \\ Esen Efeoglu \\ Technological University Dublin \\ Hugh J Byrne \\ Technological University Dublin, hugh.byrne@tudublin.ie
}

See next page for additional authors

Follow this and additional works at: https://arrow.tudublin.ie/nanolart

Part of the Biological and Chemical Physics Commons

\section{Recommended Citation}

M. Gargotti, et al. (2018) "Raman spectroscopy detects biochemical changes due to different cell culture environments in live cells in vitro", Analytical and Bioanalytical Chemistry, 410, 7537-7550 (2018)

This Article is brought to you for free and open access by the NanoLab at ARROW@TU Dublin. It has been accepted for inclusion in Articles by an authorized administrator of ARROW@TU Dublin. For more information, please contact arrow.admin@tudublin.ie, aisling.coyne@tudublin.ie,gerard.connolly@tudublin.ie.

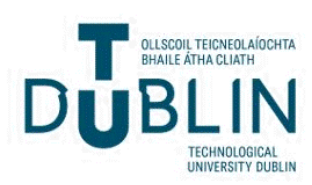


Authors

Mahmoud Gargotti, Esen Efeoglu, Hugh J Byrne, and Alan Casey

This article is available at ARROW@TU Dublin: https://arrow.tudublin.ie/nanolart/78 


\title{
Raman spectroscopy detects biochemical changes due to different cell culture environments in live cells in vitro
}

\author{
M. Gargotti ${ }^{1,2 *}$, E. Efeoglu ${ }^{1,2}$, H.J. Byrne ${ }^{2}$ and A. Casey ${ }^{1,2}$,
}

${ }^{1}$ School of Physics and Clinical \& Optometric Sciences, Nanolab Research Centre, FOCAS

Research Institute, Dublin Institute of Technology, Kevin Street, Dublin 8, Ireland.

${ }^{2}$ FOCAS Research Institute, Dublin Institute of Technology, Kevin Street, Dublin 8, Ireland.

*Corresponding author: mahmoud.gargotti@mydit.ie

\begin{abstract}
The in vitro cell culture environment can impact on cell biochemistry and cell cycle. The manifestation of such substrate-induced changes in cell cycle in the Raman microspectroscopic profiles of cell cultures is investigated at the level of nucleolus, nucleus and cytoplasm. HeLa immortalised human cervical cells and HaCaT dermal cells were cultured on three different substrates, conventional polystyrene cell culture dishes, $\mathrm{CaF}_{2}$ slides as a commonly used Raman substrate, and glass slides coated with Collagen Rat Tail, as a mimic of the extra cellular matrix (ECM) environment. A cell cycle study, based on percentage DNA content, as determined using Propidium Iodide staining and monitored by flow cytometry, was performed on cells of both types, grown on the different substrates, confirming that the in vitro cell culture environment impacts significantly on the cell cycle. Live cell in vitro Raman spectroscopic analysis of cells on the $2 \mathrm{D} \mathrm{CaF}_{2}$ and $3 \mathrm{D}$ Collagen substrates was performed and data was analysed using principal components analysis (PCA). The spectroscopic analysis revealed differences in profiles which reflect the differences in cell cycle for both in vitro culture environments. In particular, the Raman spectra of cells
\end{abstract}


grown on $\mathrm{CaF}_{2}$ show indicators of cell stress, which are also associated with cell cycle arrest at the G0/G1 phase. This work contributes to the field of Raman spectroscopic analysis by providing a fresh look at the significance of the effect of in vitro culture environment to cell cycle and the sensitivity of Raman spectroscopy to such differences in cell metabolism.

\section{Keywords}

Collagen I, cell cycle, 2D cell culture, 3D cell culture, Raman spectroscopy, live cell analysis. 


\section{Introduction}

The transition from 2D to 3D culture models in vitro has been a significant development in the understanding of differences in tumour formation mechanisms in vitro $[1,2,3,4] .3 \mathrm{D}$ cell culture has the architectural structure to mimic the in vivo environment $[5,4]$ via an extracellular matrix (ECM) and aims to produce cultures which possess the phenotype and functional characteristics of their in vivo counterparts, resulting in a more realistic biological response in vitro [3]. Over the last decade, new models such as Collagen gels and more complex multicomponent systems such as Matrigel have emerged, providing the cell a suitable ECM $[6,7]$.

It has been demonstrated that the different culture environments do not significantly affect the viability and health of the cells, and any apparent differences in viability levels between 2D and 3D culture have been demonstrated to be a result of the differing physical characteristics of the 2D and 3D environments which cause an increase in conversion rates of quantifying viability dyes $[8,9]$. However, while not necessarily affecting the viability of the cells, it has subsequently been shown that, compared to $2 \mathrm{D}$ cultures, the $3 \mathrm{D}$ environment can influence cell cycle as a result of cell cycle arrest in the G0/G1 or S phase and retardation of the S-G2/M transition, as indicated by flow cytometric analysis [10].

Raman microspectroscopy can be employed to further explore this phenomenon at a biochemical level. The technique has been shown to be a powerful analytical technique for the analysis of biological materials $[11,12,13]$, and it has a high molecular specificity. The advantages of Raman spectroscopy in the analysis of cells, tissue and bio-fluids have been extensively demonstrated in recent years $[14,15,16]$. It allows rapid, non-invasive and high spatial resolution acquisition of structural and biochemical information through the acquisition of point spectra and/or spectral images $[13,17,18,19]$. As a label free technique, 
Raman spectroscopy presents several advantages in the study of live cells compared to high content molecular analysis with optical imaging, in which cellular processes are visualised through specific labels. In comparison to infrared spectroscopic analysis, Raman offers submicron spatial resolution and has the advantage that water has a relatively weak contribution, which is an extremely strong infrared absorber. Due to these advantages, Raman spectroscopy offers a better possibility to study cells in an aqueous environment and thus keep cells alive during the experiments under normal physiological conditions [20]. The technique has thus been widely used for the analysis of cell-drug and cell nanoparticle interaction at a sub-cellular level [21, 22]. Currently, in bio-spectroscopy, one of the most widely used substrates is $\mathrm{CaF}_{2}$ windows, as the material permits the transmission of visible, near and mid IR light with low losses and UV grade $\mathrm{CaF}_{2}$ does not have any characteristic Raman bands in the cellular spectral fingerprint region $\left(400-1800 \mathrm{~cm}^{-1}\right)$ which allows the analysis of biological samples [23]. Although $\mathrm{CaF}_{2}$ has many advantages, such as low background signal and high optical transmission, this substrate is expensive and significantly increases sample analysis costs for clinical applications [24]. Standard glass and quartz have stronger backgrounds and are more frequently used during stimulated and coherent antistokes Raman setups, in which the Raman signal is relatively strong or turned to a specific wavenumber [23]. Some studies have previously investigated metal-coated Raman substrates for biological analysis [25, 26]. However, the release of metal ions in the biological environment can have adverse effects on live cultured cells, hindering the lifetime of the sample [26].

This work aims to investigate how the substrate-induced changes in cell cycle are manifest in the spectroscopic profiles of the cell cultures. To do this, and for consistency with previous studies [8, 9, 10], normal and cancer cell lines were chosen for growth on both a commercially available 3D basement membranes (Collagen) and 2D systems (Polystyrene, 
$\mathrm{CaF}_{2}$ ). The cell cycle for each cell line on each substrate was profiled using flow cytometric analysis, and the spectral signatures of the cytoplasm, nucleus and nucleolus of cells grown on standard glass slides coated with collagen were compared to those of cells on the $\mathrm{CaF}_{2}$ substrate, with the aid of principal components analysis (PCA).

\section{Materials and methods}

\subsection{Materials}

Dulbecco's Modified Eagle Medium, (Nutrient Mixture F-12, DMEM/F12), foetal bovine serum (FBS), L-glutamine, ampicillin, streptomycin, and trypsin were purchased from Sigma-Aldrich Ltd (Arklow, Co. Wicklow, Ireland). Collagen I Rat-Tail (Gibco ${ }^{\mathrm{TM}}$, Catalogue Number A1048301), was purchased from Biosciences (Dublin, Ireland).

\subsection{Cell culture}

HeLa cells (human cervical cancer; ATCC CCL-2; purchased from ATCC (Manassas, VA, USA)) and HaCaT cells (human dermal keratinocyte; purchased from the Leibnitz Institute DSMZ - German Collection of Microorganisms and Cell Cultures), were both adapted to culture in DMEM/F12 supplemented with $10 \%$ foetal bovine serum, $1 \%$ L-glutamine, penicillin and streptomycin $(50 \mathrm{mg} / \mathrm{ml}),[8,27,28,29]$, under standard conditions of $5 \% \mathrm{CO}_{2}$ at $37^{\circ} \mathrm{C}$ and humidity of $95 \%$. Cells were cultured until they reached approximately $80 \%$ confluency.

\subsection{Collagen substrate preparation}

Collagen I Rat Tail (Gibco) was used for preparation of the Collagen gel; $2.5 \mathrm{mg} / \mathrm{ml}$ sterile solution was mixed with sterile $1 \mathrm{M}$ sodium hydroxide $(\mathrm{NaOH})$, Phosphate-buffered Saline 
x10 (PBS10x) and sterile distilled water. After mixing, a $200 \mu 1$ solution was placed in Matek $35 \mathrm{~mm}$ glass bottomed culture vessels for Raman spectroscopy studies and incubated between $45 \mathrm{~min}$ and $1 \mathrm{hr}$ at $37^{\circ} \mathrm{C}$ to allow gel to formation. All preparation steps were performed on ice to ensure premature gelation did not occur.

\subsection{Flow cytometry}

Cells were seeded in T-25 $\mathrm{cm}^{2}$ flasks at a density of $1.5 \times 10^{6}(5 \mathrm{ml}$ of medium) per flask. For Collagen, two flasks pre-coated with $1 \mathrm{ml}$ Collagen $2.5 \mathrm{mg} / \mathrm{ml}$ and two flasks without Collagen (2D). For $\mathrm{CaF}_{2}$, cells were seeded at a density of $1.5 \times 10^{6}, 200 \mu \mathrm{l}$ of cell suspension were deposited per slide, on three slides and kept in polystyrene Petri dishes with $3 \mathrm{ml}$ of growth medium. Flasks were incubated in a $5 \% \mathrm{CO}_{2}$ at $37^{\circ} \mathrm{C}$ for $24 \mathrm{~h}$; all samples were analysed with the aid of a BD Accuri ${ }^{\mathrm{TM}}$ C6 Flow Cytometre.

\section{Cell cycle analysis}

Cells were grown in $3 \mathrm{D}$ and $2 \mathrm{D}$ at the same initial seeding concentration of $1.5 \times 10^{6}$ cells per flask and again $5 \mathrm{ml}$ medium volume in $\mathrm{T}-25 \mathrm{~cm}^{2}$ flasks and $3 \mathrm{ml}$ in polystyrene Petri dishes. After $24 \mathrm{hr}$ incubation, cells were washed twice with prewarmed PBS and were collected by trypsinization, after which the trypsin was removed by centrifugation (1200 RPM for eight min), after which cells were fixed in ice cold, $70 \%$ ethanol and prepared for analysis immediately or stored in the fridge for a maximum of 2 days. Briefly, for analysis, cells were washed twice with PBS, to remove any residue fixative and resuspended in $2 \mathrm{ml}$ PBS. $100 \mu \mathrm{g} / \mathrm{ml}$ Ribonuclease was added to ensure that only the DNA content was stained. After 5 min incubation with RNase at room temperature, DNA content was then stained with Propidium Iodide (PI) at a staining concentration of $50 \mu \mathrm{g} / \mathrm{ml}$. The sample was again incubated at room temperature for $20 \mathrm{~min}$, after which it was immediately analysed. A 
minimum of 10,000 single cell events per sample were analysed. The experiments were performed in triplicate.

\subsection{Sample Preparation for Spectroscopic Analysis}

HeLa and HaCaT cells were harvested by trypsin detachment and seeded in Matek $35 \mathrm{~mm}$ glass bottom culture vessels pre-coated with $100 \mu \mathrm{l}$ of collagen $2.5 \mathrm{mg} / \mathrm{ml}$ at a final concentration at a density of $1 \times 10^{5}$ cells per-dish in a volume of $200 \mu \mathrm{l}$ of $10 \%$ FBS supplemented DMEM/F12. For $\mathrm{CaF}_{2}$, cells were seeded at a density of $1 \times 10^{5}$, and $200 \mu \mathrm{l}$ of cell suspension were deposited per slide and kept in polystyrene Petri dishes with $3 \mathrm{ml}$ of growth medium. After $24 \mathrm{hr}$ incubation in $5 \% \mathrm{CO}_{2}$ humidified incubator at $37^{\circ} \mathrm{C}$, the medium was removed, cell were washed with pre-warmed PBS and medium was replaced with Phenol Red free medium supplemented with $10 \%$ FBS for spectroscopic measurements.

\subsection{Raman spectroscopy measurements}

A Horiba Jobin-Yvon LabRAM HR800 spectrometer equipped with a 785nm, $300 \mathrm{~mW}$ diode laser as source (70 $\mathrm{mW}$ at the sample), a 16-bit dynamic range Peltier cooled CCD detector, and a x100 immersion objective (LUMPlanF1, Olympus, N.A. 1.00) was employed throughout the study, producing a spot on the sample of $\sim 1 \mu \mathrm{m}$ diameter. The 300 lines $/ \mathrm{mm}$ grating and $100 \mu \mathrm{m}$ confocal hole was used to acquire spectra from the two different substrates and both cell lines (HeLa, HaCaT) in the fingerprint region, from $400 \mathrm{~cm}^{-1}$ to 1800 $\mathrm{cm}^{-1}$, and accumulated twice for 30 seconds to improve the signal to noise ratio. The system was pre-calibrated to the $520.7 \mathrm{~cm}^{-1}$ spectral line of silicon. Point spectra were acquired from subcellular regions on the different substrates, Collagen and $\mathrm{CaF}_{2} .20$ point spectra each from the cytoplasm, nucleus and nucleolus of live cells were acquired (60 spectra per cell line) and 20 cells were analysed per substrate. 


\subsection{Data analysis}

Raman spectral pre-processing and analysis were performed using Matlab 2017 (Mathworks, USA), using algorithms developed in house and the scripts are adapted from the CLIRSPEC Open Access Scripts [30]. Prior to analysis, any obvious outliers which had an anomalously high background or low signal to noise were removed from the dataset (maximum 5 per dataset of 20) and the remaining spectra were smoothed (Savitsky-Golay filter, 5th order, 7 points). The reference spectrum constituting background signal was subtracted and spectra were vector normalised to improve spectral quality and minimise the possible background contributions into the spectra. After pre-processing, principal components analysis (PCA) was employed as an unsupervised multivariate approach to analyse the Raman data. The order of the PCs denotes their importance to the dataset. PC1 describes the highest amount of variation, PC2 the second greatest and so on. In all analyses, the first two principal components accounted for $>63 \%$ of the variance of the datasets, and higher order PCs did not add further clarity to the analysis. This statistical method was preferred for this study to highlight the variability existing in the spectral data set recorded during the different experiments. Another advantage of this method is the observation of loadings which represent the variance for each variable (wavenumber) for a given PC. Analysing the loadings of a PC can give information about the source of the variability inside a data set, derived from variations in the molecular components contributing to the spectra.

\section{Results}

\subsection{Cell cycle analysis for HeLa and HaCaT cell lines on different substrates}

The cell cycle is constituted by the G1 phase (cell growth), followed by S phase (DNA synthesis), and then by G2 phase (cell growth), whence the mitotic phase is reached, at which the cell undergoes mitosis and cytokinesis, leading to the formation of two daughter cells, in 
the G0 phase, which then progress to the G1 phase, etc.. In order to determine whether there were any differences between the cell cycle profiles of the cells cultured on the 3D in comparison to the 2D substrates, cell cycle analysis studies were performed on both cell lines on polystyrene, $\mathrm{CaF}_{2}$ and Collagen, revealing significant cell line dependent differences in profiles of cell grown on different substrate/environments (Fig. 1). For the case of HaCaT cells, minimum differences are apparent between the cell cycle profiles of cells grown on polystyrene, compared to the 3D Collagen environment (Fig. 1a). The cell cycle profile of HeLa Cells, however, shows significant differences between the two (Fig. 1b), indicating relatively fewer cells in the $\mathrm{S}$ and more cells in the G2M phases in the conventional $2 \mathrm{D}$ growth environment, as previously been reported by Gargotti et al.[10].

On $\mathrm{CaF}_{2}$ substrates, favoured for Raman spectroscopic analysis, the cell cycle profile is markedly different for both cell lines. For the HaCaT cells, there were significant increases to the number of cells grown on $\mathrm{CaF}_{2}$ in the $\mathrm{G} 0 / \mathrm{G} 1$ phase, with a corresponding reduction of cells in the G2/M phase, indicating that the cells may have been arrested in the G0/G1 phase as a result of culture on the $\mathrm{CaF}_{2}$ substrate compared with those grown on 3D culture (Fig. 1a). Although elevated with respect to those on collagen, the cell populations of HeLa cells on $\mathrm{CaF}_{2}$ are not as significantly different to that of the HaCaT, the population levels in the $\mathrm{S}$ and $\mathrm{G} 2 / \mathrm{M}$ phases are similar within the standard deviations of the measurements. 

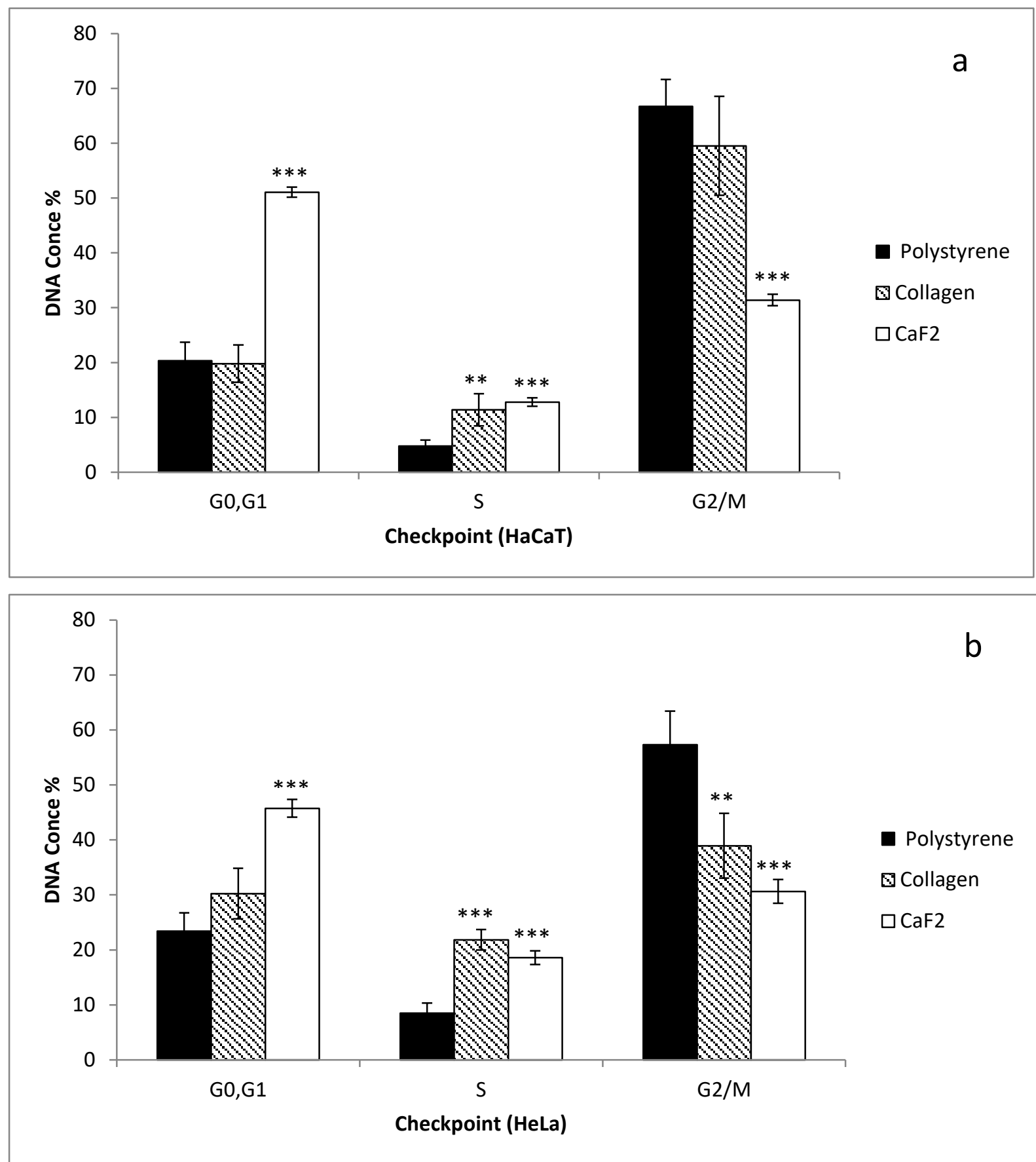

Figure 1. (a) HaCaT cell cycle analysis, cells were grown on three different substrates (Polystyrene, Collagen and $\mathrm{CaF}_{2}$ ), and percentage of cells at $\mathrm{G} 0 / \mathrm{G} 1, \mathrm{~S}$, and $\mathrm{G} 2 / \mathrm{M}$ phases of cell cycle. Data are expressed as a percentage of three independent experiments \pm SD of three individual experiments. (b) HeLa cell cycle analysis, cells were grown on three different substrates (Polystyrene, Collagen and $\mathrm{CaF}_{2}$ ), and percentage of cells at G0/G1, S, and G2/M phases of cell cycle. Data are expressed as a percentage of three independent experiments \pm SD of three individual experiments. Statistically significant differences between the $3 \mathrm{D}$ and $\mathrm{CaF}_{2}$ cultures and the polystyrene cultures are denoted by $* * \mathrm{P}<0.01$ and $* * * \mathrm{P}<0.001$. 


\subsection{Raman spectroscopic analysis of HeLa and HaCaT cells on $\mathrm{CaF}_{2}$ substrate}

The ability to acquire Raman spectra from cells in the presence of the saline without interference to the spectra has been demonstrated by [31], resulting in a series of band assignments for cellular components at molecular level [11, 32, 33] (see table 1). After initially culturing the $\mathrm{HaCaT}$ cells (normal keratinocyte) for $24 \mathrm{hr}$ on $\mathrm{CaF}_{2}$ and $3 \mathrm{D}$ culture (Collagen), the medium was replaced with phenol-free DMEM, which is used to improve the visibility of the cells and subcellular features under white light illumination, before taking any point spectra of live cells. Twenty-point spectra were acquired from each cellular region of 20 different cells, as previously described by Bonnier et al. [31]. Figure 2 shows scatter plots of PCA (a) and the loading of the first PC (b) corresponding to cytoplasm, nucleus and nucleolus of $\mathrm{HaCaT}$ cells grown on $\mathrm{CaF}_{2}$. Different cellular regions are indicated respectively by, blue for cytoplasm, red for nucleus and green for nucleolus. The spectra corresponding to the nucleus and nucleolus (nuclear areas) are clearly differentiated from cytoplasm of $\mathrm{HaCaT}$ cells grown on $\mathrm{CaF}_{2}$ according to PC1 (Explained variance 41\%) based on their biochemical features. In the first PCA loading obtained from comparison of the combined nuclear region and cytoplasm of $\mathrm{HaCaT}$ cells grown in $\mathrm{CaF}_{2}$, the spectra relating to the cytoplasm of $\mathrm{HaCaT}$ cells scored negatively $(\mathrm{PC} 1<0)$, while nucleus and nucleolus spectra scored positively (PC1 $\geq 0$ ) (Fig. 2 b). To facilitate the analysis of the loadings, table 1 details common assignments of cellular spectral features derived from literature $[11,32,33]$. In the loading, positive features are dominated by nucleic acid features (785 and $810 \mathrm{~cm}^{-1}$ ) corresponding to biochemical composition of nucleus and nucleolus. On the other hand, negative features of the first loading show lipid and protein features such as those at 715, 1003, 1438 and 1600$1700 \mathrm{~cm}^{-1}$ (Fig. 2 b, table 1). Similar differentiating profiles have previously been observed, for example for lung cancer cell lines [34]. 


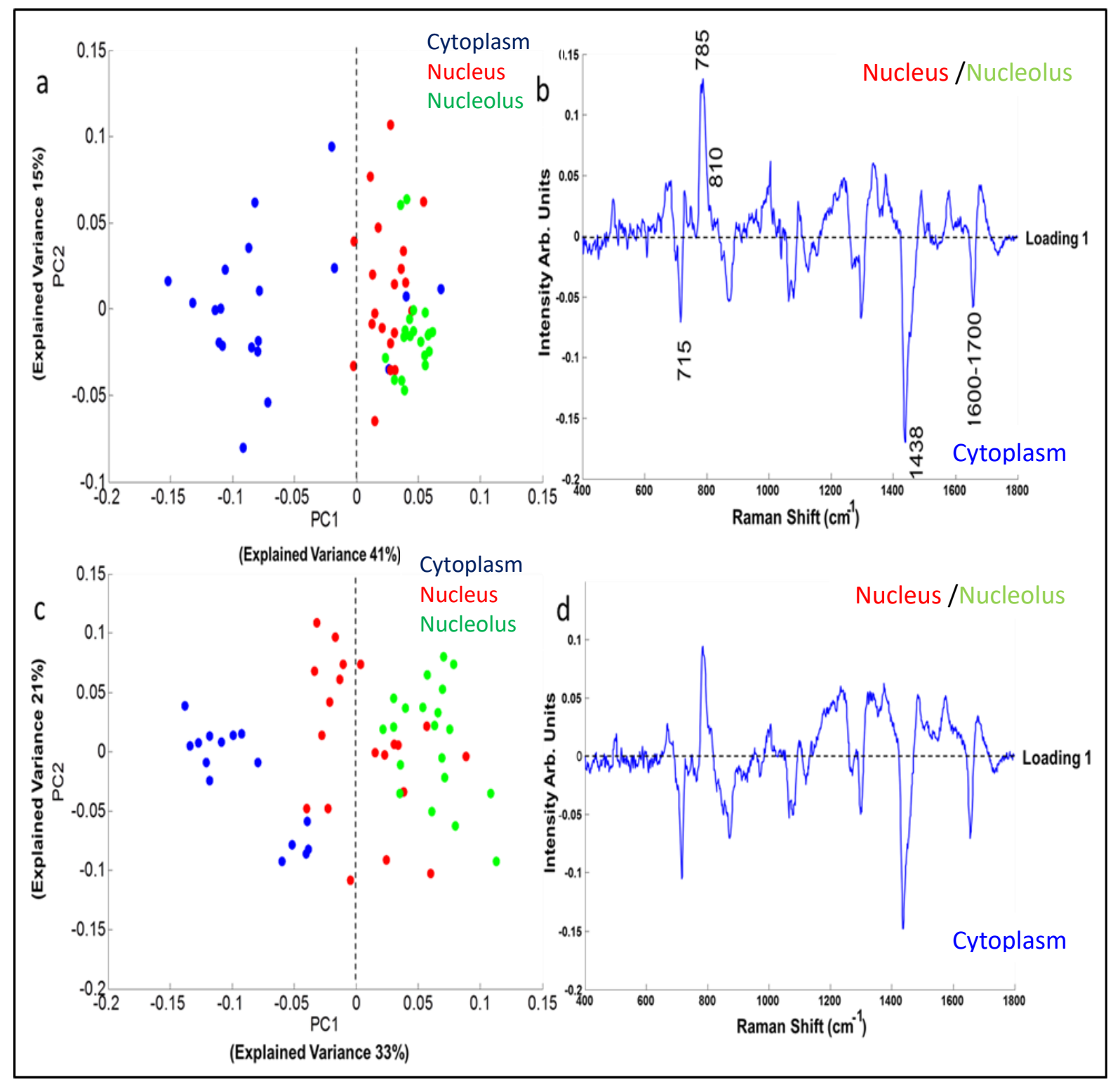

Figure 2. PCA scatter plot (a) and loading of PC1 (b), corresponding to comparison of cytoplasm, nucleus and nucleolus region of $\mathrm{HaCaT}$ cells grown on $\mathrm{CaF}_{2}$ substrate. The ' 0 ' line is indicated with black dashes. PCA scatter plot (c) and loading of PC1 (d) corresponding to comparison of cytoplasm region, nucleus and nucleolus region of HeLa cells grown on $\mathrm{CaF}_{2}$ substrate. The ' 0 ' line is indicated with black dashes.

HeLa cells were cultured under the exact same conditions as the HaCaT cells and the same data acquisition was applied. Briefly, the $\mathrm{HeLa}$ cells were grown on $\mathrm{CaF}_{2}$ and $3 \mathrm{D}$ culture (Collagen) and spectra were acquired from cytoplasm, nucleus and nucleolus of individual cells. Figure 2 shows the scatter plots (2c) and the first loading of PCA (2d), corresponding to 
cytoplasm, nucleus and nucleolus of HeLa cells grown on $\mathrm{CaF}_{2}$. The spectra corresponding to the nucleolus are clearly differentiated from the cytoplasm of $\mathrm{HeLa}$ cells grown on $\mathrm{CaF}_{2}$ according to $\mathrm{PC}$, although, in comparison with the observations for $\mathrm{HaCaT}$ cells, the spectra for the nucleus are less well differentiated, and straddle the positive and negative sides of PC1, which represents the most significant variance (33\%) among the data. The loading of PC1 of HeLa cells grown in $\mathrm{CaF}_{2}$, is nevertheless dominated on the positive side by nucleic acid features associated with the nuclear region and negative features of protein features associated with the cytoplasm (Fig. 2 d). The differentiating loadings of PC1 in figure 2 are remarkably similar for the two cell lines and are consistent with those observed in numerous studies of a range of cell lines, conducted under similar experimental conditions [31, 34, 35].

A comparison between $\mathrm{HeLa}$ and $\mathrm{HaCaT}$ cells grown on $\mathrm{CaF}_{2}$ and $3 \mathrm{D}$ culture (Collagen) was performed. Figure 3 shows the scatter plots and the loading of the first PCs corresponding to a pairwise comparison of cytoplasm, nucleus and nucleolus of HeLa and HaCaT cell lines after $24 \mathrm{hr}$ growth on the $\mathrm{CaF}_{2}$ substrate. The scatter plots of PCA and data sets relating to the different cell lines are colour coded, blue for $\mathrm{HaCaT}$ cells and red for HeLa cells. Although a complete differentiation is not observed for any of the subcellular regions, the data is partially discriminated for each. The spectra relating to HaCaT cells predominantly scored negatively according to $\mathrm{PC} 1(\mathrm{PC} 1<0)$, while those of HeLa cells scored positively $(\mathrm{PC} 1 \geq 0)$. The different cell lines are best differentiated by their nucleolar regions, consistent with the studies of different lung cell lines, by Farhane et al. [34]. 


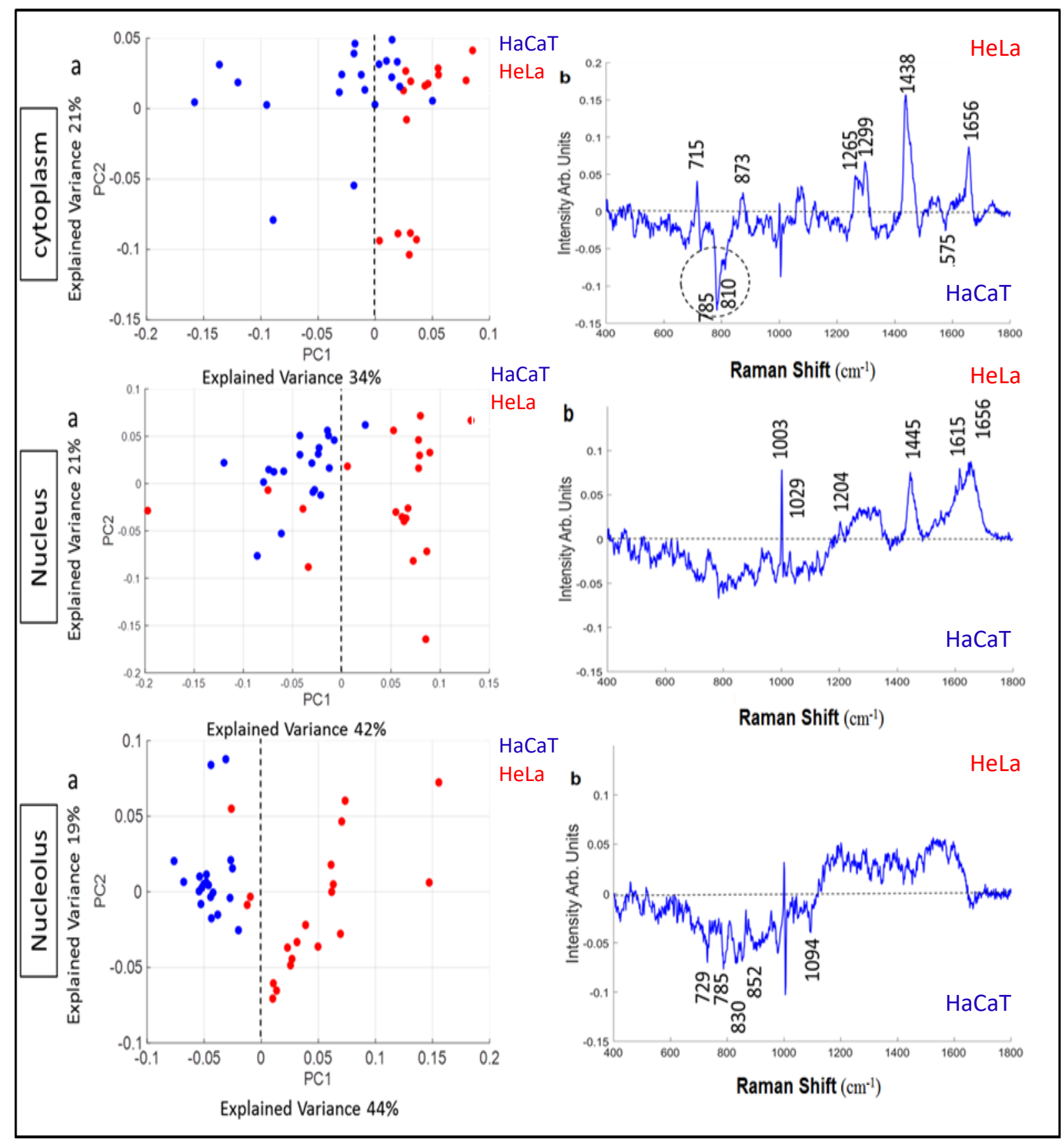

Figure 3. PCA scatter plots (a) and loadings of PC1 (b), corresponding to comparison of cytoplasm, nucleus and nucleolus of $\mathrm{HaCaT}$ and HeLa cells grown on $\mathrm{CaF}_{2}$. The ' 0 ' line of PC1 is indicated with black dashes. Band positions corresponding to dominant features of the PC1 are indicated on the loadings.

Figure 3a (cytoplasm) shows the scatter plots of PCA corresponding to pairwise comparison of the cytoplasm of HeLa and HaCaT cell lines according to PC1, which represents the most significant variance $(34 \%)$ among the data, originating from biochemical differences in the 
cytoplasm of the different cell lines. Figure 3b (cytoplasm) shows the loading of the first PC, corresponding to cytoplasm of HeLa and HaCaT cells. The predominant features which differentiate the $\mathrm{HeLa}$ and $\mathrm{HaCaT}$ cells are the positive features associated with phospholipids, nucleic acid, lipids, protein, collagen, DNA and RNA $\left(715-9,873 \mathrm{~cm}^{-1}, 1265\right.$ $\mathrm{cm}^{-1}, 1299 \mathrm{~cm}^{-1}$ and $\left.1655-80 \mathrm{~cm}^{-1}\right)$. On the other hand, the dominant negative features include those associated with DNA/RNA and amino acids $\left(785 \mathrm{~cm}^{-1}, 810 \mathrm{~cm}^{-1}\right.$ and $1575 \mathrm{~cm}^{-}$ ${ }^{1}$ ) (table 1). Figure 3a (nucleus) compares the spectra corresponding to the nucleus of HeLa and $\mathrm{HaCaT}$ cell lines according to $\mathrm{PC} 1$, which represents the most significant variance (42 $\%$ ) among the data, originating from biochemical differences in nucleus of different cell lines. Figure $3 b$ (nucleus) shows the loading of the first PC, which differentiates the nucleus of HeLa and HaCaT cells. The predominant features which differentiate the HeLa and HaCaT cells are identified as the positive features characteristic of amino acid, methoxy groups, collagen, phospholipids, protein and lipids $\left(1003 \mathrm{~cm}^{-1}, 1029 \mathrm{~cm}^{-1}, 1204 \mathrm{~cm}^{-1}, 1445 \mathrm{~cm}^{-1}\right.$, $1615 \mathrm{~cm}^{-1}$ and $1655-80 \mathrm{~cm}^{-1}$ ) (table 1). Figure $3 \mathrm{a}$ (nucleolus) shows the spectra corresponding to the nucleolus of HeLa and HaCaT cell lines according to PC1, which represent the most significant variance (44\%) among the data. Figure $3 \mathrm{~b}$ (nucleolus) shows the first loading of the PCA, corresponding to the nucleoli of HeLa and HaCaT cells. The positive features of the loading are dominated by HeLa cell related bands, while negative features relate to the $\mathrm{HaCaT}$ cells. The predominant features which are used to differentiate the HeLa and HaCaT cells are observed as the negative features associated with amino acid, nucleic acid and DNA/RNA $\left(729 \mathrm{~cm}^{-1}, 785 \mathrm{~cm}^{-1}, 830 \mathrm{~cm}^{-1}, 852 \mathrm{~cm}^{-1}\right.$ and $\left.1094 \mathrm{~cm}^{-1}\right)$ (table 1). 
Table 1. Assignments of Raman Bands of cells grown on $\mathrm{CaF}_{2}$ and Collagen substrate $[11,32,33]$.

\begin{tabular}{|c|c|}
\hline Band & Assignment \\
\hline $715-9 \mathrm{~cm}^{-1}$ & $\begin{array}{l}\mathrm{C}-\mathrm{N} \text { (membrane phospholipids head)/adenine, } \mathrm{CN}_{2}\left(\mathrm{CH}_{3}\right)_{3} \text { (lipids), } \\
\text { choline group }\end{array}$ \\
\hline $729 \mathrm{~cm}^{-1}$ & Adenine \\
\hline $785 \mathrm{~cm}^{-1}$ & $\begin{array}{l}\mathrm{U}, \mathrm{T}, \mathrm{C} \text { (ring breathing modes in the DNA/RNA bases), backbone } \mathrm{O}- \\
\mathrm{P}-\mathrm{O} \text { (RNA) }\end{array}$ \\
\hline $810 \mathrm{~cm}^{-1}$ & phosphodiester (Z-marker) DNA \\
\hline $830 \mathrm{~cm}^{-1}$ & proline, hydroxyproline, tyrosine, $v_{2} \mathrm{PO}_{2}$ stretch of nucleic acids \\
\hline $850 \mathrm{~cm}^{-1}$ & $\begin{array}{l}\text { most probably due to single bond stretching vibrations for the amino } \\
\text { acids and valine and polysaccharides }\end{array}$ \\
\hline $852 \mathrm{~cm}^{-1}$ & proline, hydroxyproline, tyrosine \\
\hline $873 \mathrm{~cm}^{-1}$ & symmetric breathing of tryptophan (protein assignment) \\
\hline $918 \mathrm{~cm}^{-1}$ & proline, hydroxyproline \\
\hline $938 \mathrm{~cm}^{-1}$ & proline, hydroxyproline \\
\hline $980 \mathrm{~cm}^{-1}$ & C-C stretching $\beta$-sheet (proteins) \\
\hline $1003 \mathrm{~cm}^{-1}$ & phenylalanine, C-C skeletal \\
\hline $1029 \mathrm{~cm}^{-1}$ & $\mathrm{O}-\mathrm{CH} 3$ stretching of methoxy groups \\
\hline $1081 \mathrm{~cm}^{-1}$ & $v_{1} \mathrm{CO}_{3}{ }^{2}, v_{3} \mathrm{PO}_{4}{ }^{3}, v(\mathrm{C}-\mathrm{C})$ skeletal of acyl backbone in lipid or collagen \\
\hline $1094 \mathrm{~cm}^{-1}$ & DNA \\
\hline $1167 \mathrm{~cm}^{-1}$ & lipid \\
\hline $1184 \mathrm{~cm}^{-1}$ & Guanine, Cytosine \\
\hline $1249 \mathrm{~cm}^{-1}$ & Amide III, Guanine and Cytosine \\
\hline $1265 \mathrm{~cm}^{-1}$ & $\begin{array}{l}\text { Amide III of collagen, Amide III (collagen assignment), Amide III, } \\
v(\mathrm{CN}), \delta(\mathrm{NH}) \text { amide III, } \alpha \text {-helix, collagen (protein assignment) }\end{array}$ \\
\hline $1299 \mathrm{~cm}^{-1}$ & Lipid \\
\hline $1315 \mathrm{~cm}^{-1}$ & Guanine (B, Z-marker) \\
\hline $1335 \mathrm{~cm}^{-1}$ & nucleic acid, collagen \\
\hline $1438 \mathrm{~cm}^{-1}$ & $\mathrm{CH}_{3}, \mathrm{CH}_{2}$ deformation \\
\hline
\end{tabular}




\begin{tabular}{|c|l|}
\hline $1445 \mathrm{~cm}^{-1}$ & $\delta\left(\mathrm{CH}_{2}\right), \delta\left(\mathrm{CH}_{3}\right), \mathrm{CH}_{2} \mathrm{CH}_{3}$ bending \\
$1448-9 \mathrm{~cm}^{-1}$ & $\mathrm{CH}_{2} \mathrm{CH}_{3}$ deformation \\
$1575 \mathrm{~cm}^{-1}$ & $\begin{array}{l}\text { ring breathing modes in the DNA bases, } \mathrm{G}, \mathrm{A} \text { (ring breathing modes of } \\
\text { the DNA/RNA bases) } \\
\text { phenylalanine, hydroxyproline }\end{array}$ \\
$1587 \mathrm{~cm}^{-1}$ & $\begin{array}{l}\text { tyrosine, tryptophan, } \mathrm{C}=\mathrm{C} \text { (protein) } \\
1615 \mathrm{~cm}^{-1}\end{array}$ \\
$1655-80 \mathrm{~cm}^{-1}$ & $\mathrm{C}=\mathrm{C}$ (lipids), Amide I (proteins) \\
$1660 \mathrm{~cm}^{-1}$ & Amide I \\
\hline
\end{tabular}

\subsection{Raman spectroscopic analysis of HeLa and HaCaT cells on Collagen substrates}

Figure 4 shows the scatter plots (a) and the first loadings of PCA (b) corresponding to cytoplasm, nucleus and nucleolus of $\mathrm{HaCaT}$ cells grown on 3D culture (Collagen). The spectra corresponding to the nucleus and nucleolus (nuclear areas) are clearly differentiated from those of the cytoplasm of HaCaT cells grown on 3D culture (Collagen), according to PC1 which represents the most significant variance (34\%) among the data originating from differences in biochemical composition between the nuclear and cytoplasmic areas. According to the loading of PC1 of HaCaT cells grown in 3D culture (Collagen), the spectra relating to the cytoplasm of $\mathrm{HaCaT}$ cells scored negatively $(\mathrm{PC} 1<0)$, while nuclear and nucleolus spectra scored positively (PC1 $\geq 0$ ) (Fig. 4 b). 


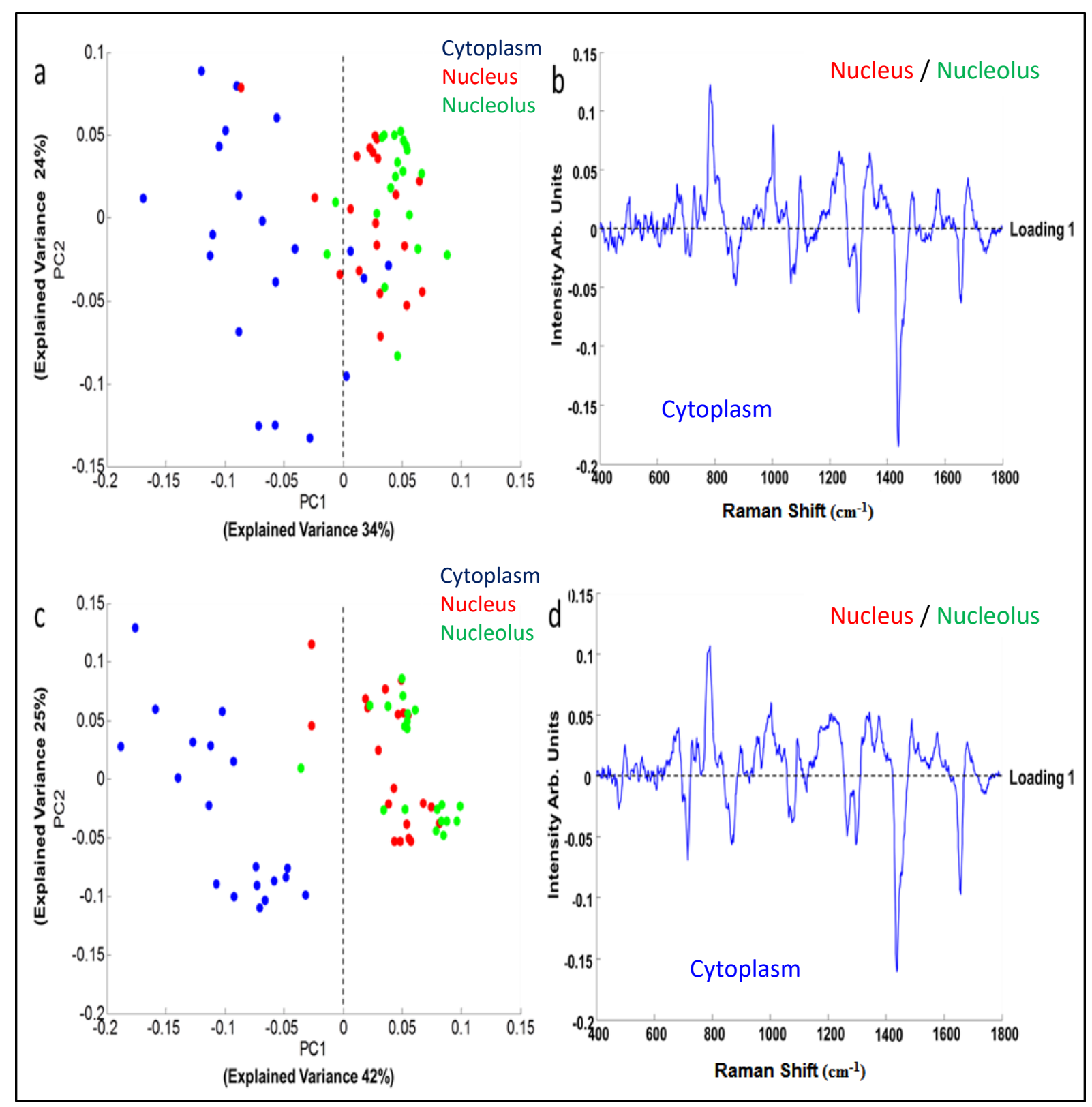

Figure 4. PCA Scatter plot(a) and loading of PC1 (b) corresponding to comparison of cytoplasm region, nucleus and nucleolus region of $\mathrm{HaCaT}$ cells grown on $3 \mathrm{D}$ culture (Collagen). The ' 0 ' line is indicated with black dashes. PCA scatter plot (c) and loading of PC1 (d) corresponding to comparison of cytoplasm region, nucleus and nucleolus region of HeLa cells on $3 \mathrm{D}$ culture (Collagen). The ' 0 ' line is indicated with black dashes.

Figure 4 shows the PCA scatter plot (c) and the loading of PC1 (d) corresponding to cytoplasm, nucleus and nucleolus of HeLa cells grown on 3D culture (Collagen). Different cellular regions are colour coded as before, blue for cytoplasm, red for nucleus and green for nucleolus, respectively. In contrast to the spectra obtained from $\mathrm{CaF}_{2}$, the spectra 
corresponding to the nucleus and nucleolus (nuclear areas) are clearly differentiated from those of the cytoplasm of HeLa cells grown on 3D culture (Collagen), according to PC1 (explained variance 42\%). According to the loading of PC1 obtained from comparison of nuclear region and cytoplasm of HeLa cells grown in 3D culture (Collagen), the spectra relating to the cytoplasm of $\mathrm{HeLa}$ cells scored negatively $(\mathrm{PC} 1<0)$, while nuclear and nucleolus spectra scored positively $(\mathrm{PC} 1 \geq 0$ ) (Fig. 4 d). Notably, although a better discrimination between the subcellular regions of HaCaT cells was observed, the differentiating profiles of PC1 obtained from the analysis of cellular compartments of HeLa cells on $\mathrm{CaF}_{2}$ and collagen surfaces showed a high degree of consistency in terms of Raman spectral bands in negative and positive features of the loadings.

Figure 5 shows the scatter plots and the loading of the first PC corresponding to cytoplasm, nucleus and nucleolus of HeLa and HaCaT cells lines after $24 \mathrm{hr}$ growth in 3D culture (Collagen). The scatter plots of PCA and data sets relating to substrates are colour coded as, blue for HaCaT cells and red for HeLa cells. Figure 5a (cytoplasm) shows the spectra corresponding to the cytoplasm of $\mathrm{HeLa}$ and $\mathrm{HaCaT}$ cell lines according to PC1, which represent the most significant variance (37\%) among the data, originating from biochemical differences of the cytoplasm of the different cell lines. The spectra relating to the cytoplasm of $\mathrm{HaCaT}$ scored negatively according to $\mathrm{PC} 1(\mathrm{PC} 1<0)$, while the cytoplasm of HeLa spectra scored positively $(\mathrm{PC} 1 \geq 0)$. Figure $5 \mathrm{~b}$ (cytoplasm) shows the first loading of the PCA, corresponding to pairwise comparison of cytoplasm of HeLa and HaCaT cells. The positive features of loading 1 can be attributed to HeLa cells, while negative features represent HaCaT cells. The most dominant features which differentiate the HeLa and HaCaT cells are the positive features of lipids/phospholipids, nucleic acids, DNA/RNA, amino acids and collagen $\left(717-9 \mathrm{~cm}^{-1}, 785 \mathrm{~cm}^{-1}, 810 \mathrm{~cm}^{-1}, 850 \mathrm{~cm}^{-1}, 918 \mathrm{~cm}^{-1}, 938 \mathrm{~cm}^{-1}, 1003 \mathrm{~cm}^{-1}, 1081 \mathrm{~cm}^{-1}, 1265\right.$ $\mathrm{cm}^{-1}, 1299 \mathrm{~cm}^{-1}, 1438 \mathrm{~cm}^{-1}$ and $1655-80 \mathrm{~cm}^{-1}$ ) (table 1). Figure 5a (nucleus) shows the 
spectra corresponding to the nucleus of HeLa and $\mathrm{HaCaT}$ cell lines according to PC1, which represents the most significant variance (31\%) among the data, originating from biochemical differences in the nucleus of different cell lines. The spectra relating to the nucleus of $\mathrm{HaCaT}$ scored negatively according to PC1 $(\mathrm{PC} 1<0)$, while those of the nucleus of HeLa spectra score positively $(\mathrm{PC} 1 \geq 0)$. Figure $5 \mathrm{~b}$ (nucleus) shows the first loading of the $\mathrm{PCA}$, corresponding to cytoplasm of $\mathrm{HeLa}$ and $\mathrm{HaCaT}$ cells. The positive features of the loading of PC1 represent the differentiating biochemical features of HeLa cells, while negative features relate to the HaCaT cells. The most dominant features which differentiate the HeLa and HaCaT cells are the positive features of phospholipids/lipids, nucleic acids, DNA/RNA, amino acids, proteins and collagen $\left(717-9 \mathrm{~cm}^{-1}, 785 \mathrm{~cm}^{-1}, 850 \mathrm{~cm}^{-1}, 938 \mathrm{~cm}^{-1}, 980 \mathrm{~cm}^{-1}, 1003\right.$ $\mathrm{cm}^{-1}, 1029 \mathrm{~cm}^{-1}, 1094 \mathrm{~cm}^{-1}, 1249 \mathrm{~cm}^{-1}, 1335 \mathrm{~cm}^{-1}, 1448-9 \mathrm{~cm}^{-1}$ and $1656-80 \mathrm{~cm}^{-1}$ ) (table 1). On the other hand, the dominant negative features include those of lipids, guanine, cytosine, adenine and dipeptides $\left(1167 \mathrm{~cm}^{-1}, 1184 \mathrm{~cm}^{-1}\right.$ and $\left.1587 \mathrm{~cm}^{-1}\right)$.

Figure 5a (nucleolus) shows the spectra corresponding to the nucleolus of HeLa and HaCaT cell lines according to $\mathrm{PC} 1$, which represent the most significant variance (35\%) among the data, originating from biochemical differences in nucleolus. The spectra relating to the nucleolus of HaCaT scored negatively $(\mathrm{PC} 1<0)$, while nucleolus of HeLa spectra scored positively according to $\mathrm{PC} 1$ ( $\mathrm{PC} 1 \geq 0$ ). Figure $5 \mathrm{~b}$ (nucleolus) shows the first loading of the PCA, corresponding to nucleolus of HeLa and HaCaT cells. The positive features of the loading of PC1 can be related to HeLa cells, while negative features relate to the HaCaT cells. The most prominent loadings which differentiate the HeLa and HaCaT cells are the positive features of phospholipids/lipids, nucleic acid, DNA/RNA, proteins, Guanine, collagen and protein $\left(717-9 \mathrm{~cm}^{-1}, 785 \mathrm{~cm}^{-1}, 980 \mathrm{~cm}^{-1}, 1094 \mathrm{~cm}^{-1}, 1315 \mathrm{~cm}^{-1}, 1335 \mathrm{~cm}^{-1}\right.$, $1448-9 \mathrm{~cm}^{-1}, 1575 \mathrm{~cm}^{-1}$ and $1660 \mathrm{~cm}^{-1}$ ) (table 1). 


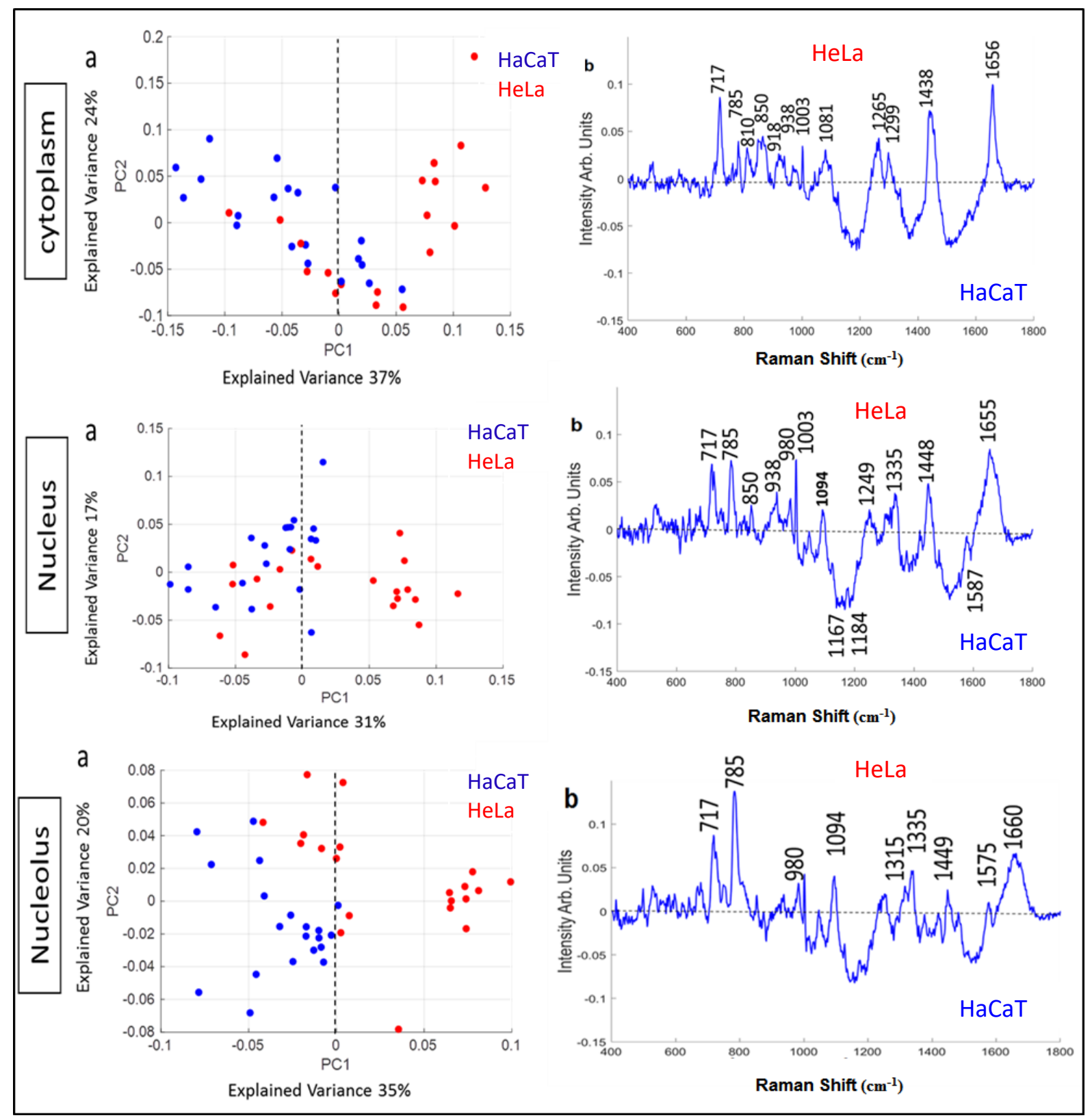

Figure 5. Scatter plots (a) and first loadings of PCA (b) corresponding to comparison of cytoplasm, nucleus and nucleolus of HaCaT and HeLa cells on 3D culture (Collagen). The ' 0 ' line is indicated with black dashes. Band positions corresponding to dominant features of the $\mathrm{PC} 1$ are provided on the loadings.

\subsection{Comparison between $\mathrm{CaF}_{2}$ and Collagen}

A comparison between the spectra of cells grown on $\mathrm{CaF}_{2}$ and $3 \mathrm{D}$ culture (Collagen) was performed (see supplementary materials); scatter plots and the loadings of the first PC 
corresponding to cytoplasm, nucleus and nucleolus of HeLa and HaCaT cells are provided in figures 6 and 7, respectively.

Figure 6 is a representation of the scatter plots obtained from the pairwise comparison of different cellular regions of HeLa cells grown on $\mathrm{CaF}_{2}$ and Collagen substrates. Notably, for all cellular regions, HeLa cells show little or no discrimination between 3D culture (Collagen) and $\mathrm{CaF}_{2}$ in the scatter plots of PCA (Fig. 6 a-c).

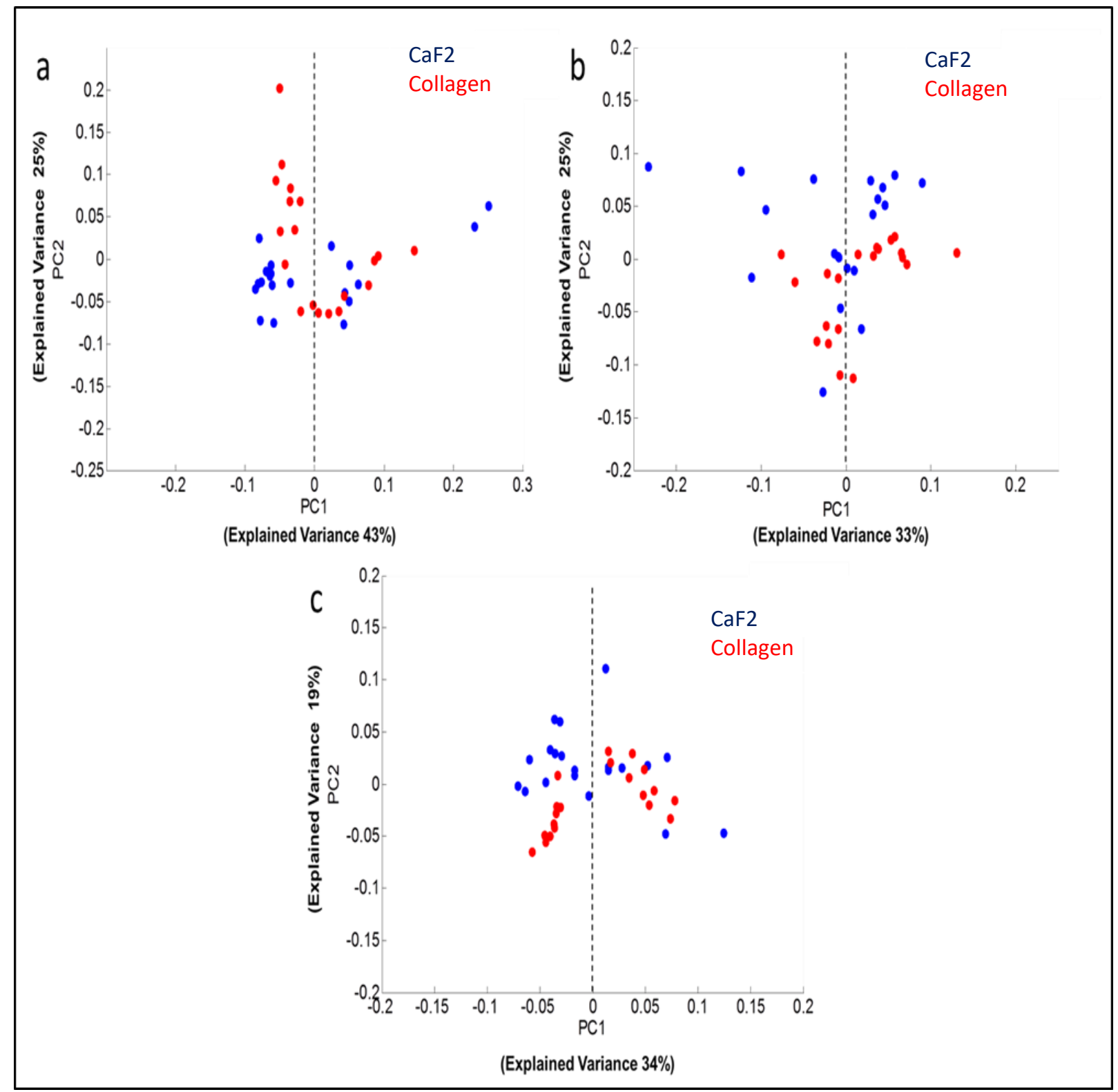


Figure 6. Scatter plots of PCA corresponding to comparison of cytoplasm (a), nucleus (b) and nucleolus (c) of HeLa cells grown on $\mathrm{CaF}_{2}$ and $3 \mathrm{D}$ culture Collagen substrate. The black dashes are used to indicate the ' 0 ' line.

Figure 7 is a representation of the plots obtained from pairwise comparison of cytoplasm, nucleus and nucleolus of $\mathrm{HaCaT}$ cells grown on different substrates. In contrast to the results from HeLa cells, clear discrimination is observed between 3D culture (Collagen) and $\mathrm{CaF}_{2}$ in the scatter plots of PCA for each subcellular region (Fig. 7). The scatter plots of PCA and data sets relating to the different cell lines are colour coded, blue for HaCaT cells grown on $\mathrm{CaF}_{2}$ and red for $\mathrm{HaCaT}$ cells grown in collagen. The spectra relating to cells on $\mathrm{CaF}_{2}$ predominantly scored negatively according to $\mathrm{PC} 1(\mathrm{PC} 1<0)$, while those cells in Collagen scored positively $(\mathrm{PC} 1 \geq 0)$. Figure 7 (a) (cytoplasm) shows the spectra corresponding to the cytoplasm of $\mathrm{HaCaT}$ cells on $\mathrm{CaF}_{2}$ and $\mathrm{HaCaT}$ cells in collagen according to PC1, which represent the most significant variance $(51 \%)$ among the data, originating from biochemical differences in the cytoplasm of the cells grown on different substrates. Figure $7 b$ (cytoplasm) shows the loading of the first $\mathrm{PC}$, corresponding to cytoplasm of $\mathrm{HaCaT}$ cells grown on $\mathrm{CaF}_{2}$ and $\mathrm{HaCaT}$ cells grown in Collagen. The dominant negative features include those of phospholipids/lipids, nucleic acid, DNA/RNA and amino acid $\left(717 \mathrm{~cm}^{-1}, 785 \mathrm{~cm}^{-1}, 1003 \mathrm{~cm}^{-1}\right.$ and $1094 \mathrm{~cm}^{-1}$ ) (table 1). Figure 7a (nucleus) compares the spectra corresponding to the nucleus of $\mathrm{HaCaT}$ cells grown on $\mathrm{CaF}_{2}$ and $\mathrm{HaCaT}$ cells grown in Collagen according to PC1, which represents the most significant variance (52\%) among the data, originating from biochemical differences in nucleus of different substrates. Figure $7 b$ (nucleus) shows the loading of the first PC, which differentiates the nucleus of $\mathrm{HaCaT}$ cells grown on $\mathrm{CaF}_{2}$ and HaCaT cells grown in collagen. The predominant features, which differentiate the HaCaT cells grown on $\mathrm{CaF}_{2}$ and $\mathrm{HaCaT}$ cells grown in Collagen, are identified as lipids in the positive loadings $\left(1438 \mathrm{~cm}^{-1}\right)$, while the dominant negative features include those of 
phospholipids/lipids, nucleic acid, DNA/RNA and amino acids $\left(717-9 \mathrm{~cm}^{-1}, 785 \mathrm{~cm}^{-1}, 1003\right.$ $\mathrm{cm}^{-1}$ and $1094 \mathrm{~cm}^{-1}$ ) (table 1). Figure 7a (nucleolus) shows the spectra corresponding to the nucleolus of $\mathrm{HaCaT}$ cells grown on $\mathrm{CaF}_{2}$ and on Collagen according to $\mathrm{PC} 1$, which represents the most significant variance $(63 \%)$ among the data. Figure $7 \mathrm{~b}$ (nucleolus) shows the first loading of the PCA, corresponding to the nucleoli of $\mathrm{HaCaT}$ cell grown on $\mathrm{CaF}_{2}$ and HaCaT cells grown in collagen. The negative features of the loading are dominated by HaCaT cells grown on $\mathrm{CaF}_{2}$ related bands, while positive features relate to the $\mathrm{HaCaT}$ cells grown in Collagen. The predominant differentiating features are observed as the positive features of lipids at $1438 \mathrm{~cm}^{-1}$ and the negative features of phospholipids/lipids, nucleic acid, DNA/RNA, amino acids $\left(717-9 \mathrm{~cm}^{-1}, 785 \mathrm{~cm}^{-1}, 1003 \mathrm{~cm}^{-1}, 1094 \mathrm{~cm}^{-1}\right.$ and $1575 \mathrm{~cm}^{-1}$ ) (table $1)$. 


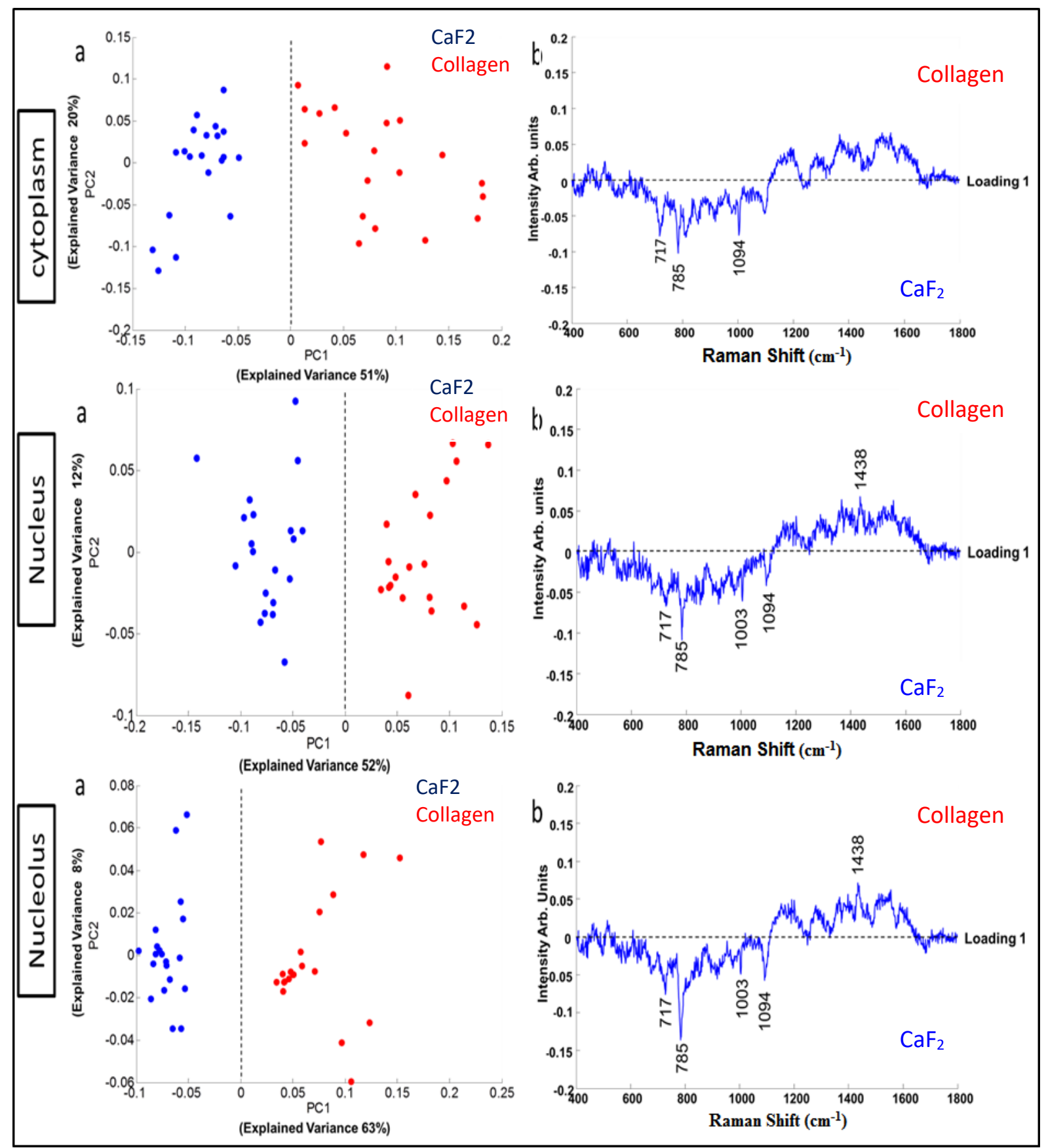

Figure 7. Scatter plots and first loadings of PCA corresponding to comparison of cytoplasm, nucleus and nucleolus of $\mathrm{HaCaT}$ cells on $\mathrm{CaF}_{2}$ and $3 \mathrm{D}$ culture Collagen substrate. The ' 0 ' line is indicated with black dashes.

\section{Discussion}

3D culture better mimics the extracellular conditions encountered by cells in their native environment and can facilitate the acquisition of accurate information on cell differentiation, migration and cell homeostasis $[5,36]$. 3D cell culture has the architectural structure to 
mimic the in vivo extra cellular matrix (ECM) and aims to produce cultures which possess the phenotype and functional characteristics of their in vivo counterparts, resulting in a more realistic biological response in vitro [3]. New models such as Collagen and more complex multicomponent systems such as Matrigel have been developed to provide an ECM to grow the cells in vitro [7, 37]. However, a number of studies have shown that there can be modifications to the cell composition, metabolism and also phenotype when the cells are grown in ECM compared to 2D culture [38, 39].

The translation from 2D culture to 3D culture has been seen to influence cell cycle by inducing an interruption at the S-phase of cell cycle, as evidenced by flow cytometric analysis of cell cycle phase transitions using a Propidium Iodide stain for the DNA content [10]. Notably, in comparison to cells grown in a conventional 2D environment (Polystyrene), significant differences in the cell cycle profile of both cell lines was observed on the $\mathrm{CaF}_{2}$ substrate, manifest as significantly higher cell numbers in the G0/G1 phase, and correspondingly lower numbers in the $\mathrm{S}$ and $\mathrm{G} 2 / \mathrm{M}$ phases, particularly for the case of $\mathrm{HaCaT}$ cells. A different trend is observed for the Collagen substrates, although to a lesser extent, and therefore there is a greater similarity of the profiles of the conventional polystyrene Petri dish and 3D collagen environment, particularly for the HaCaT cell line. Comparing the cell cycle profiles of the two cell lines, the differences between the $2 \mathrm{D} \mathrm{CaF}_{2}$ and collagen environment are more pronounced for the HaCaT cell line.

In this study, we used two different types of cell lines which represent normal and cancer cells models, and are among the most commonly used human cell lines in scientific research. The PCA of data collected in this work demonstrates a clear separation and they do not show high variances. In all cases, the cellular samples are mixed populations, and microscopically, the different phases of the cell cycle are not discernible. The Raman microspectroscopic profiling of the subcellular regions is of random cell selections within the population. In the 
case where the subcellular regions of the cells are not mutually differentiated, as is the case for example for the comparison of cell lines on either $\mathrm{CaF}_{2}$ or collagen substrates (Fig. 3 and 5), or HeLa cells on $\mathrm{CaF}_{2}$ compared to collagen (Fig. 6), pairwise PCA simply identifies the variance within the combined dataset, and the PC loading represents that variance. Although some differences in cell cycle profile are evident in Fig 1a, b, as discussed in "Cell cycle analysis for HeLa and HaCaT cell lines on different substrates" section, these differences are not apparent in the comparison of the spectral profiles of the subcellular regions, indicating that it is difficult to directly correlate such differences in cell cycle profile with the spectroscopic profiles.

Spectroscopically, $\mathrm{HaCaT}$ cells grown on the $\mathrm{CaF}_{2}$ and collagen environments are best differentiated in all subcellular regions, as shown in figure 7. Notably, comparing the cell cycle profiles for the two different substrates in figure 1a, it can be seen that the most significant differences are the relative populations in the G0/G1, and in the G2/M phases. The loadings of the differentiating PCs in figure 7 indicate distinctive nucleic acid contributions for all subcellular regions, particularly that at $785 \mathrm{~cm}^{-1}$, assigned to ring breathing modes of the DNA/RNA bases, as well as backbone O-P-O stretching of RNA. Notably, in all cases, these present as positive bands for cells grown on $\mathrm{CaF}_{2}$, and a similar differentiating profile is observed for the nucleoli of $\mathrm{HaCaT}$ cells compared to HeLa, on $\mathrm{CaF}_{2}$. This feature, and the doublet of features at $785 \mathrm{~cm}^{-1}$ and $810 \mathrm{~cm}^{-1}$ observed in the differentiating loading for cytoplasm of $\mathrm{HaCaT}$ vs $\mathrm{HeLa}$ cells grown on $\mathrm{CaF}_{2}$ (Fig. 3), have previously been observed in studies of oxidative stress in nanoparticle exposed cell cultures, and may be related to noncoding RNA formation as a result of reactive oxygen species generation [22]. This band has also been seen to be prominent in the study of the subcellular interactions of the chemotherapeutic agent, doxorubicin, particularly in the cell nucleus and nucleolus [40]. The 
spectroscopic differentiation reveals therefore signatures of cellular stress, which are not evident in the $3 \mathrm{D}$ cell culture environment.

$\mathrm{CaF}_{2}$ is a microcrystalline material, which in itself renders it as an ideal substrate for either infrared or Raman spectroscopy, as any intrinsic vibrational modes are low frequency, below the fingerprint regions of biological interest $\left(<500 \mathrm{~cm}^{-1}\right)$ [41]. It is generally considered biocompatible, and therefore optimal for Raman microscopic profiling of cells [26]. However, the cell cycle profiles of figures $1 \mathrm{a}$ and $1 \mathrm{~b}$ clearly show that the cell populations are significantly perturbed by the crystalline substrate. In contract, the cell cycle profiles of the conventional 2D polystyrene Petri dish and 3D collagen substrates are comparable, at least for HaCaT cells. For HeLa cells, in contrast, there is a significant difference between the cell cycle profiles on the conventional 2D and 3D substrates [10].

\section{Conclusion}

The study demonstrates that the cell culture environment can considerably influence the cell cycle profile, and therefore the diversity of biochemical profiles of individual cells within a mixed cell population, depending on substrate and also cell type. Using Raman microspectroscopy, these differences manifest as spectroscopic markers of cellular stress which are particularly prominent in cells on $\mathrm{CaF}_{2}$ substrates, widely used for Raman analysis. The study therefore flags a potentially important consideration for applications of Raman spectroscopy for cellular analysis, particularly of external factors such as anti cancer agents whose mode of action are understood to be cell cycle specific [42].

In contrast, the ECM mimicking material, Collagen is seen to be an ideal substrate for Raman spectroscopic measurements it absorbs the cell culture medium, facilitating a pro-longed 
viability of cultured cells, even on glass substrates, and when compared to $\mathrm{CaF}_{2}$, it is minimally disruptive to the cell cycle profile, as measured against cells grown on conventional polystyrene Petri dish substrates.

As a substrate for Raman microscopy, due to its low density, collagen has minimal contribution to the spectral background. The underlying glass substrate has similarly negligible contribution and, in immersion, the background is that of the medium, dominated by water, facilitating spectral pre-processing. Preparation time is low and the Collagen option is therefore significantly lower cost when compared to standard Raman substrates strengthening its potential.

\section{Acknowledgements}

This study was funded by the Government of Libya for M. Gargotti and this work has been enabled by Science Foundation Ireland Principle Investigator Award 11/PI/1108.

\section{Compliance with ethical standards}

\section{Conflict of interest}

The authors declare that they have no conflict of interest. 


\section{References}

1. Freshney RI . Culture of animal cells. A manual of basic technique, 5th ed. Wiley; 2005.

2. Antoni D, Burckel H, Josset E, Noel G . Three-dimensional cell culture: a breakthrough in vivo. Int J Mol Sci; 2015. 16:5517-5527.

3. Padmalayam I, Suto M J . 3D cell cultures. Mimicking in vivo tissues for improved predictability in drug discovery. Annu Rep Med Chem. 2012; 47:367-378.

4. Breslin S \& O'Driscoll L . Three-dimensional cell culture: the missing link in drug discovery. Drug Discov Today . 2013;18(5-6):240-249

5. Kim J Bin . Three-dimensional tissue culture models in cancer biology.

Semin Cancer Biol. 2005. 15(5), pp.365-77

6. Prestwich G D . Evaluating Drug Efficacy and Toxicology in Three Dimensions: Using Synthetic Extracellular Matrices in Drug Discovery. Acc Chem Res. 2008. 41(1), pp.139-148

7. Weaver V M, Howlett A R, Langton-Webster B, Petersen O W, Bissell M J . The development of a functionally relevant cell culture model of progressive human breast cancer. Semin Cancer Biol. 1995. 6(3), pp.175-184

8. Casey A, Gargotti M, Bonnier F, Byrne H J . Chemotherapeutic efficiency of drugs in vitro: Comparison of doxorubicin exposure in 3D and 2D culture matrices. Toxicol In Vitro. 2016. 33, pp.99-104

9. Bonnier F, Keating M E, Wróbel T, Majzner K, Baranska M, Garcia A, Blanco A, and Byrne, H J . Cell viability assessment using the Alamar blue assay: A comparison of 2D and 3D cell culture models. Toxicol In Vitro. 2015 pp.124-131 
10. Gargotti M, Lopez-Gonzalez U, Byrne H J, Casey A . Comparative studies of cellular viability levels on 2D and 3D in vitro culture matrices. Cytotechnology. 2017. DOI 10.1007/s10616-017-0139-7.

11. Notingher I . Raman Spectroscopy Cell-based Biosensors. Sensors. 2007. 7, pp.13431358

12. Ember K, Hoeve M, Mcaughtrie S, Bergholt M S, Dwyer B, Stevens M M, Faulds K, Forbes S \& Campbell C . 'Raman Spectroscopy and Regenerative Medicine: A Review' NPJ Regen Med. 2017 vol 2, no. 1. DOI: 10.1038/s41536-017-0014-3

13. Butler H J, Ashton L, Bird B, Cinque G, Curtis K, Dorney J, Esmonde-White K, Fullwood N J, Gardner B, Martin-Hirsch P L, Walsh M J, McAinsh M R, Stone N, Martin F L . Using Raman spectroscopy to characterize biological materials. Nat Protoc. 2016. 11(4), pp.664-687

14. Ellis D I, Cowcher D P, Ashton L, O'Hagan S and Goodacre R (2013). Illuminating disease and enlightening biomedicine: Raman spectroscopy as a diagnostic tool. Analyst. 2013. 138(14), p.3871

15. Clemens G, Hands J R, Dorling K M and Baker M J . Vibrational spectroscopic methods for cytology and cellular research. Analyst. 2014. 139(18), pp.4411-4444

16. Liu Y, Zhu Y \& Li Z . Application of Raman spectroscopy in Andrology: non-invasive analysis of tissue and single cell. Transl Androl Urol. 2014. 3(1), pp.125-33

17. Lieber C A, Majumder S K, Billheimer D, Ellis D L, Mahadevan-Jansen A . Raman microspectroscopy for skin cancer detection in vitro. J Biomed Opt. 13(April) 2008. p. 24013

18. Swain R J \& Stevens M M . Raman microspectroscopy for non-invasive biochemical analysis of single cells. Biochem Soc Trans. 2007. 35(Pt 3), pp.544-549

19. Notingher I \& Hench L L . Raman microspectroscopy: a noninvasive tool for studies of individual living cells in vitro. Expert Rev Med Devices. 2006. 3(2), pp.215-234 
20. Draux F, Jeannesson P, Beljebbar A, Tfayli A, Fourre N, Manfait M, Sulé-Suso J, Sockalingum GD . Raman spectral imaging of single living cancer cells: a preliminary study. Analyst. 2009. 134(3), pp.542-548

21. Farhane Z, Nawaz H, Bonnier F and Byrne H J . In vitro label free screening of chemotherapeutic drugs using Raman micro-spectroscopy: towards a new paradigm of spectralomics. J. Biophotonics. 2017. 00258. doi:10.1002/jbio.201700258

22. Efeoglu E, Maher M A, Casey A and Byrne H J . Toxicological Assessment of Nanomaterials: The role of in vitro Spectroscopic Analysis. Anal Bioanal Chem. 2017. doi.org/10.1007/s00216-017-0812-x

23. Gee A R, O'Shea D C \& Cummins H Z (1966). Raman scattering and fluorescence in calcium fluoride. Solid State Commun. 1966. 4(1), pp.43-46

24. Baker M J, Byrne H J, Chalmers J, Gardner P, Goodacre R, Henderson A, Kazarian S, Martin F L, Moger J, Stone N \& Sulé-Suso J . 'Clinical Applications of Infrared and Raman Spectroscopy: State of Play and Future Challenges'. Analyst. 2018. doi: 10.1039/c7an01871a.

25. Cui L, Butler H J, Martin-Hirach P L and Martin Fl . Aluminium foil as a potential substrate for ATR-FTIR, transflection FTIR or Raman spectrochemical analysis of biological specimens. Anal. Methods. 2016. 8(3), pp.481-487

26. Kerr L T, Byrne H J \& Hennelly B M . Optimal choice of sample substrate and laser wavelength for Raman spectroscopic analysis of biological specimen. Anal. Methods. 2015. 7(12), pp.5041-5052

27. Cody D, Casey A, Naydenova I, Mihaylova E . A Comparative Cytotoxic Evaluation of Acrylamide and Diacetone Acrylamide to Investigate Their Suitability for Holographic Photopolymer Formulations. Int J Polym Sci. 2013. 2013, pp.1-6

28. Herzog E, Casey A, Lyng F M, Chambers G, Byrne H J, Davoren M . A new approach to the toxicity testing of carbon-based nanomaterials - The clonogenic assay. Toxicol Lett. 2007. 174(1-3), pp.49-60 
29. Mukherjee S G, O'Claonadh N, Casey A, Chambers G . Comparative in vitro cytotoxicity study of silver nanoparticle on two mammalian cell lines. Toxicol In Vitro. 2012. 26(2), pp.238-251

30. Henderson A . Clirsec-summer-school (2015), [Accessed 28 July 2018, 13:20], https://zenodo.org/communities/clirspec/?page $=1 \&$ size $=20$

31. Bonnier F, Knief P, Meade A, Dorney J, Bhattacharya K, Lyng F and Byrne H . Imaging live cells grown on a three dimensional collagen matrix using Raman microspectroscopy. Analyst. 2010. 135(12), pp.3169-3177

32. Movasaghi Z, Rehman S \& Rehman I U. Raman Spectroscopy of Biological Tissues, Appl Spectrosc Rev. 2007. 42:5, 493-541, DOI: 10.1080/05704920701551530

33. Pobezhimova T P and Voinikov V K . Biochemical and physiological aspects of ubiquinone function. Membr Cell Biol. 2000. 13, 595-602

34. Farhane Z, Bonnier F, Casey A, Maguire A, O’Neill L and Byrne H J . Cellular discrimination using in vitro Raman micro spectroscopy: the role of the nucleolus. Analyst. 2015. 140, 5908-5919. doi:10.1039/c5an01157d

35. Efeoglu E, Casey A, Byrne H J . In vitro monitoring of time and dose dependent cytotoxicity of aminated nanoparticles using Raman spectroscopy. Analyst. 2016. 141, 5417-5431, DOI: 10.1039/C6AN01199C.

36. Kim J Bin, Stein R \& O'Hare M J . Three-dimensional in vitro tissue culture models of breast cancer-- a review. Breast Cancer Res Treat. 2004. 85(3), pp.281-291

37. Petersen O W, Rønnov-Jessen L, Howlett A R, and Bissell M J . Interaction with basement membrane serves to rapidly distinguish growth and differentiation pattern of normal and malignant human breast epithelial cells. Proc Natl Acad Sci U S A. 1992. 89(19), pp.9064-8

38. Lupanova T, Stefanova N, Petkova D, Staneva G, Jordanova A, Koumanov K, Pankov R, Momchilova A . Alterations in the content and physiological role of sphingomyelin in plasma membranes of cells cultured in three-dimensional matrix. Mol Cell Biochem. 2010. 340(1-2), pp.215-22 
39. Wu Y M, Tang J, Zhao P, Chen Z N, Jiang J L . Morphological changes and molecular expressions of hepatocellular carcinoma cells in three-dimensional culture model. Exp Mol Pathol. 2009. 87(2), pp.133-40

40. Farhane Z, Bonnier F \& Byrne H J . Monitoring doxorubicin cellular uptake and trafficking using in vitro Raman microspectroscopy: short and long time exposure effects on lung cancer cell lines. Anal Bioanal Chem. 2017. 409: 1333

41. Crystran. "Raman Substrate Materials." Raman

Gradehttps://Www.crystran.co.uk/Raman-Substrate-Materials Calcium Fluoride, [Accessed 15 Apr. 2018, 15:33], www.crystran.co.uk/raman-substrate-materials

42. Stewart Z A, Westfall M D, Pietenpol J A . Cell-cycle dysregulation and anticancer therapy. Trends Pharmacol Sci. 2003. 24:139-145. 


\section{Supplementary Material:}

\section{Raman spectra recorded on different substrates}

A good substrate for biological applications of Raman spectroscopy should have characteristics such as an adherent surface to support the culture of cells, and the background signal should be low to avoid masking the Raman signals from the sample. The polystyrene of conventional Petri dishes itself has a strong Raman signatures, many of the bands of which overlap with features of interest for analysis of cellular spectra, and thus Raman compatible substrates such as $\mathrm{CaF}_{2}$ are favoured [1]. Figure $\mathrm{S} 1$ shows the mean Raman spectra obtained from 3D culture (Collagen on glass) and $\mathrm{CaF}_{2}$ substrates. The data recorded from different substrates show that the $3 \mathrm{D}$ culture and $\mathrm{CaF}_{2}$ yield similar spectra. No specific features from the Collagen or the underlying glass can be seen and the $\sim 1640 \mathrm{~cm}^{-1}$ band in the $\mathrm{CaF}_{2}$ and the Collagen spectrum is that of the water [2].

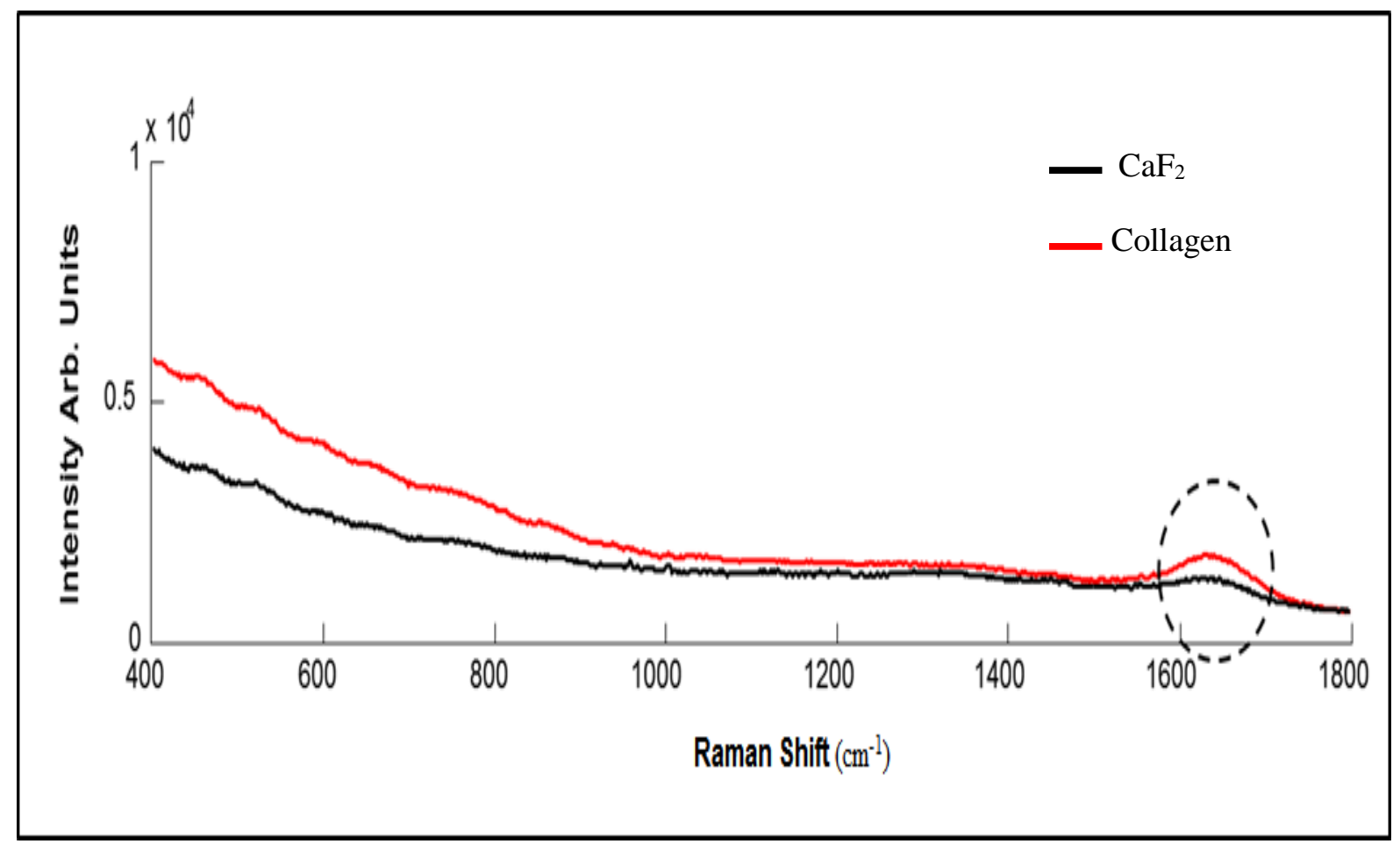


Figure S1. Comparison of Raman spectra of two substrates. Mean spectrum of Collagen and $\mathrm{CaF}_{2}$ are indicated with red and black, respectively. The dashed circle highlights the characteristic contribution of water at $\sim 1640 \mathrm{~cm}^{-1}$.

\section{Supplementary References}

1. Kerr L T, Byrne H J \& Hennelly B M . Optimal choice of sample substrate and laser wavelength for Raman spectroscopic analysis of biological specimen. Anal. Methods. 2015. 7(12), pp.5041-5052

2. Bonnier F, Knief P, Meade A D, Dorney J, Bhattacharya K, Lyng F M and Byrne H J . Collagen matrices as an improved model for in vitro study of live cells using Raman microspectroscopy. Proc SPIE Int Soc Opt Eng. 2011. 8087 